\title{
Performance, blood parameters, and carcass yield of broiler chickens supplemented with Mexican oregano oil
}

\author{
Gerardo Méndez Zamora¹, Lorenzo Antonio Durán Meléndez², Michael E. Hume³, Ramón Silva \\ Vázquez $^{4^{*}}$ \\ ${ }^{1}$ Universidad Autónoma de Nuevo Leon, Facultad de Agronomia, Escobedo, Nuevo Leon, Mexico. \\ 2 Universidad Autónoma de Chihuahua, Departamento de Nutrición Animal, Chihuahua, Chihuahua, Mexico. \\ ${ }^{3}$ U.S. Department of Agriculture, Agricultural Research Service, Southern Plains Agricultural Research Center, Food and Feed Safety Research Unit, \\ College Station, Texas, USA. \\ ${ }^{4}$ Centro de Investigación para los Recursos Naturales, Salaices, Lopez, Chihuahua, Mexico.
}

\begin{abstract}
The objective of the current study was to evaluate performance, blood parameters, and carcass yield of broilers supplemented with Mexican oregano oil. A total of 162 one-day-old broilers were randomly distributed into three dietary treatments: control diet (without oregano oil or antibiotic); control diet $+0.25 \mathrm{~g} \mathrm{~kg}^{-1}$ of oxytetracycline; and control diet $+0.4 \mathrm{~g} \mathrm{~kg}^{-1}$ of Mexican oregano oil. Treatment with organ oil had positive effects on body weight at 35 and 42 days. Feed intake was significantly different at 21 and at 1-42 days; control treatment presented the highest feed intake at 28 and 35 days, while treatment with oxytetracycline had the lowest feed intake from 21 to 42 days. Weekly body weight gain was different at 42 days, in which treatment with oregano oil was the highest and control the lowest. Feed efficiency rate was significantly different at 42 and at 1-42 days; treatment with oxytetracycline and treatment with oregano oil had the best values over control treatment. Blood parameters were found different among treatments, in which treatment with oregano oil was the highest in cholesterol and high-density lipoprotein at 42 days. Carcass and blood biometric variables were not different among treatments. The amount of $0.4 \mathrm{~g} \mathrm{~kg}^{-1}$ of Mexican oregano oil in diets improves high-density lipoprotein, body weight, and feed efficiency rate of broiler chickens.
\end{abstract}

Key Words: blood profile, broilers, Mexican oregano

\section{Introduction}

Antibiotics have been used prophylactically and in disease control. However, the European Union has banned antibiotic use in animal feed production out of concerns for bacterial resistance and hazards to public health (Hong et al., 2012). The ban has prompted researchers to study natural additives for growth promoter, antibiotic, and antioxidant properties in animal production (Adil et al., 2011; Hong et al., 2012; Cho et al., 2014; Park et al., 2014; Mohiti-Asli and Ghanaatparast-Rashti, 2015; Hashemipour et al., 2016). Hippenstiel et al. (2011) stated that oregano essential oil (OEO) has antimicrobial and antioxidant properties and

Received: March 2, 2016

Accepted: February 4, 2017

*Corresponding author: rsilva63@yahoo.com

http://dx.doi.org/10.1590/S1806-92902017000600006

How to cite: Méndez Zamora, G.; Durán Meléndez, L. A.; Hume, M. E. and Silva Vázquez, R. 2017. Performance, blood parameters, and carcass yield of broiler chickens supplemented with Mexican oregano oil. Revista Brasileira de Zootecnia 46(6):515-520.

Copyright (C) 2017 Sociedade Brasileira de Zootecnia. This is an Open Access article distributed under the terms of the Creative Commons Attribution License (http://creativecommons.org/licenses/by/4.0/), which permits unrestricted use, distribution, and reproduction in any medium, provided the original work is properly cited. stimulate the secretion of digestive enzymes. Lee et al. (2003) and Zhang et al. (2005) described OEO as having antifungal and antiviral properties. These researchers also demonstrated that OEO stimulate appetite and improve digestion and respiratory disorders. In addition, OEO is generally recognized as safe (GRAS; Silva and Dunford, 2005).

The main active components of OEO are thymol and carvacrol, which can improve feed digestibility, due to positive effects on nutrient digestibility (Jamroz et al., 2005), and induce a higher secretion of bile acids (Hashemipour et al., 2016). Oil extracts of Origanum vulgare L. tested in broiler diets improve body weight and feed intake at 1,000 ppm (Bozkurt et al., 2009), 500 ppm (MohitiAsli and Ghanaatparast-Rashti, 2015), 100 and $250 \mathrm{ppm}$ (Symeon et al., 2009), 150 and 300 ppm (Kirkpinar et al., 2011), while $200 \mathrm{ppm}$ of thymol and carvacrol (Lee et al., 2003; Hassanpour et al., 2013; Silva Vázquez et al., 2015; Hashemipour et al., 2016) also result in improvements in chicken performance.

Most studies involving oregano oil extracts have used OEO from Origanum vulgare L. and some results have led to several controversies regarding efficiency in broilers (Kirkpinar et al., 2011; Hong et al., 2012; Cho et al., 2014; 
Park et al., 2014; Mohiti-Asli and Ghanaatparast-Rashti, 2015; Hashemipour et al., 2016). Moreover, little attention has been given to Mexican oregano oil (MOO), prepared from Lippia berlandieri Schauer, in broiler production, and its use in broilers in Mexico and other countries has not been documented extensively. Therefore, the hypothesis is that MOO has potential in the intensive production of broilers as supplement in diets and as a nutraceutical additive (Gopi et al., 2014). The objective of the current study was to evaluate performance, blood parameters, and carcass yield of broilers supplemented with Mexican oregano oil. The data obtained will benefit oregano and broiler producers.

\section{Material and Methods}

Procedures used in this study were approved by the local Care and Animal Welfare Committee in Chihuahua, Chihuahua, Mexico. The city is located between the $28^{\circ} 38^{\prime} \mathrm{N}$ and $106^{\circ} 04^{\prime} \mathrm{W}$ parallels at an altitude of 1,440 m, with a mean annual temperature $18{ }^{\circ} \mathrm{C}$, annual precipitation between $200-600 \mathrm{~mm}$, and with a tempered dry climate (INEGI, 2013). Broilers were handled according to guidelines established in the Norma Oficial Mexicana (NOM-062-ZOO-1999) on care and animal welfare.

A total of 162 one-day-old Ross commercial genetic line broilers were used in this study. The birds were not vaccinated against diseases. Feed and water were offered ad libitum. Broilers were managed according the methodology of Cho et al. (2014): room temperature began at $33{ }^{\circ} \mathrm{C}$ from day 0 to 3 and was reduced gradually to $24{ }^{\circ} \mathrm{C}$ until the end of the experiment. Relative humidity fluctuated by $50 \%$, while the lighting regimen consisted of $23 \mathrm{~h}$ of light and $1 \mathrm{~h}$ of dark.

The supplied diet was isoproteic and isoenergetic and ingredients were based according to NRC (1994). Starter and finisher diets provided from 0 to 21 and 22 to 42 days of age (Table 1) were formulated according to Silva Vázquez et al. (2015). Mexican oregano essential oil, prepared by steam distillation of Lippia berlandieri Schauer, was purchased from Natural Solutions S.M.I. (Jimenez, Chihuahua, Mexico). The main components of MOO (24.63\% 1,8-cineole, $10.57 \%$ p-cymene, $0.11 \%$ $\gamma$-terpinene, $4.06 \%$ thymol, and $60.62 \%$ carvacrol) were determined by gas chromatography (Clarus 600 and MS Clarus SQ8 Perkin Elmer USA company) according to Dunford and Silva (2005).

Three treatments were evaluated: the control diet with no additives; control diet $+0.25 \mathrm{~g} \mathrm{~kg}^{-1}$ of oxytetracycline (Bayer Pfizer Inc, New York City, USA); and control diet +
$0.4 \mathrm{~g} \mathrm{~kg}^{-1}$ of Mexican oregano oil. A completely randomized design was used for the distribution of treatments in metabolic cages $(30 \times 33 \times 44 \mathrm{~cm})$, with two chickens in each cage and 54 chickens in each treatment group.

The initial weight $(\mathrm{g})$ of each broiler was determined on the first day of the experiment. The productive variables evaluated were body weight (BW; g) and feed intake (FI; g) at $7,14,21,28,35$, and 42 days. These measurements were used to estimate the weekly body weight gain (WBWG; $\left(\mathrm{BW}_{\text {current }}-\mathrm{BW}_{\text {previous }} /\right.$ week) and feed efficiency (FI/WBWG). Blood variables were measured ( $\mathrm{n}=10$ blood samples): cholesterol (CHOL), triglycerides, high-density lipoproteins (HDL), low-density lipoprotein (LDL), very low-density lipoprotein (VLDL), and blood biometrics (erythrocytes, hemoglobin, heterophils, eosinophil mean corpuscular volume, lymphocytes, monocytes, and mean corpuscular hemoglobin) according to Cohn et al. (1988), Medway et al. (1969) and Benjamin (1984). Blood samples were obtained by puncture of the left vein of broilers at 42 days of age according to Hong et al. (2012) with some modifications. Blood samples were immediately centrifuged for $15 \mathrm{~min}$ at $1,938 \times \mathrm{g}$ to obtain serum and were stored in Eppendorf tubes at $-20{ }^{\circ} \mathrm{C}$ until analysis. Cholesterol and triglycerides were determined according to Cohn et al. (1988) in serum samples and were measured in duplicate by spectrophotometry; a commercial kit (Spinreact; Stanbio Laboratory, Boerne, Texas, USA) was used for this analysis. At 42 days, carcass yield was determined in twenty chickens per treatment for slaughter weight (SW),

Table 1 - Ingredients of the starter and finisher diets for broilers

\begin{tabular}{lcc}
\hline & \multicolumn{2}{c}{ Diet $^{2}$} \\
\cline { 2 - 3 } Ingredient $\left(\mathrm{g} \mathrm{kg}^{-1}\right)^{1}$ & $\begin{array}{c}\text { Starter } \\
(0-21 \text { days })\end{array}$ & $\begin{array}{c}\text { Finisher } \\
(22-42 \text { days })\end{array}$ \\
\hline Corn & 467.2 & 556.4 \\
Soybean $(48 \%$ crude protein) & 392.2 & 312.9 \\
Corn gluten & 53.3 & 44.4 \\
Vitamin and mineral premix & 11.7 & 13.3 \\
Calcium carbonate & 14.4 & 21.4 \\
Dicalcium phosphate & 21.3 & 22.2 \\
Sodium chloride & 6.0 & 6.4 \\
DL-methionine & 1.9 & 0.8 \\
Canola oil & 32.0 & 22.2 \\
Calculated contents & & \\
Metabolizable energy (ME; kcal kg-1 $)^{3}$ & $3,200.0$ & $3,200.0$ \\
Crude protein (\%) & 23.0 & 19.0 \\
Lysine (\%) & 1.1 & 0.9 \\
Methionine + cystine (\%) & 0.9 & 0.62 \\
Calcium (\%) & 1.0 & 0.8 \\
Available phosphorus (\%) & 0.5 & 0.3 \\
\hline
\end{tabular}

${ }^{1}$ Ingredients were incorporated per $\mathrm{kg}$ of the experimental diet (expressed on a dry matter basis)

2 Diets were formulated according to the nutrient requirements for broilers as recommended by NRC (1994).

${ }^{3}$ Calculated contents according to typical values for broiler well-balanced diets providing 3,200 kcal ME kg-1. 
hot carcass weight $(\mathrm{HCW})$, cold carcass weight $(\mathrm{CCW})$, hot carcass yield $[(\mathrm{HCW} / \mathrm{SW}) \times 100]$, and cold carcass yield $[(\mathrm{CCW} / \mathrm{SW}) \times 100]$.

The data obtained from the performance variables were analyzed using the general lineal model (GLM) of SAS (Statistical Analysis System, version 9.0), considering fixed effects of treatment, and day of fattening, considering initial weight as covariate in the statistical model (Wang and Goonewardene, 2004). Performance of blood variables and meat yield were analyzed through the analysis of variance obtained with the GLM procedure of SAS, establishing the treatments as fixed effects in the statistical model. A significance level of $\mathrm{P}<0.05$ was used to detect significant statistical differences among treatments and when the P-value was less than 0.05 , the treatment means were compared with the Tukey test.

\section{Results and Discussion}

Mexican oregano oil $(60.62 \%$ carvacrol and $4.06 \%$ thymol) had significant effect $(\mathrm{P}<0.01)$ on $\mathrm{BW}$ at 35 and 42 days and not at the other days tested (Table 2). The influence of MOO was notable at 35 and 42 days, at which times, BW in the group treated with Mexican oregano was higher than in the antibiotic treatment group and the control group. Similar effects were found by Cho et al. (2014) when phytogenic additives were included in the diet of chickens. Other studies showed improvements in BW at 21 and 42 days when the chickens were fed peppermint, thyme leaves, and thymol with cinnamaldehyde or carvacrol (Ocak et al., 2008; Tiihonen et al., 2010; Mohiti-Asli and Ghanaatparast-Rashti, 2015; Hashemipour et al., 2016). In the present study, feed intake was different at days 21 and $1-42(\mathrm{P}<0.01)$, as well as at 28 and 35 days $(\mathrm{P}<0.05)$, in which the oxytetracycline treatment group consumed less feed, followed by MOO treatment group, while control group had the highest FI throughout the study (1-42 days) (Table 2). Feed intake decreased in the antibiotic treatment group. Similar results were obtained by Cabuk et al. (2006) and Küçükyılmaz et al. (2014).

In the present study, WBWG showed significance at 42 days, in which the MOO treatment group had the highest and control the lowest value $(\mathrm{P}=0.05)$ (Table 3 ). Performance efficiency results obtained by Basmacioğlu et al. (2004) with oregano oil were lower than results found in the current investigation with MOO. Silva Vázquez et al. (2015) found improvements in productive efficiency when evaluating 400 and $800 \mathrm{mg} \mathrm{kg}{ }^{-1}$ of MOO. Karimi et al. (2010) showed differences in composition between Mediterranean and Mexican oregano oils, finding different responses in performance of broiler chickens.

Feed efficiency was significantly $(\mathrm{P}<0.05)$ affected at 42 and 1-42 days (Table 3). Feed efficiency values of antibiotic and oregano oil treatment groups were not statistically different, which were different from control. These results coincide partially with Cho et al. (2014), who found improved feed efficiency with the addition of phytogenic additives $\left(250 \mathrm{mg} \mathrm{kg}^{-1}\right.$; oregano, cinnamaldehyde, carvacrol, yucca extract, and a herb mix) compared with a commercial antibiotic $\left(10 \mathrm{mg} \mathrm{kg}^{-1}\right.$ of avilamycin) and the control with no additives. Hong et al. (2012) found similar results when an essential oil mix (125 ppm including essential oil from oregano, anise, and citrus peel) was included in the diet. These authors

Table 2 - Effect of Mexican oregano oil on broiler body weight and feed intake

\begin{tabular}{|c|c|c|c|c|c|c|c|}
\hline \multirow{2}{*}{ Treatment $^{1}$} & \multicolumn{7}{|c|}{ Day } \\
\hline & Initial weight & 7 & 14 & 21 & 28 & 35 & 42 \\
\hline & \multicolumn{7}{|c|}{ Body weight (g) } \\
\hline $\mathrm{T} 1$ & 35.40 & 151.29 & 427.05 & 854.84 & $1,454.39$ & $2,064.63 b$ & $2,604.31 b$ \\
\hline $\mathrm{T} 2$ & 35.04 & 152.92 & 424.70 & 842.37 & $1,431.71$ & $2,049.84 \mathrm{~b}$ & $2,651.73 b$ \\
\hline T3 & 33.65 & 151.57 & 426.74 & 899.09 & $1,494.16$ & $2,138.01 \mathrm{a}$ & $2,763.42 \mathrm{a}$ \\
\hline SEM & 0.28 & 3.85 & 8.94 & 8.45 & 27.59 & 25.16 & 39.08 \\
\hline \multirow[t]{3}{*}{ P-value } & & 0.9496 & 0.9800 & 0.0611 & 0.3546 & 0.0123 & 0.0109 \\
\hline & 7 & 14 & 21 & 28 & 35 & 42 & $1-42$ \\
\hline & \multicolumn{7}{|c|}{ Feed intake (g) } \\
\hline $\mathrm{T} 1$ & 197.34 & 244.05 & $563.25 \mathrm{a}$ & $996.10 \mathrm{a}$ & $1,257.48 \mathrm{a}$ & $1,048.45$ & $4,287.40 \mathrm{a}$ \\
\hline $\mathrm{T} 2$ & 180.63 & 240.82 & $528.52 b$ & $930.73 b$ & $1,176.32 b$ & $1,040.03$ & $4,103.43 b$ \\
\hline $\mathrm{T} 3$ & 182.78 & 232.91 & $532.51 b$ & $934.47 b$ & $1,182.13 b$ & $1,043.21$ & $4,109.41 b$ \\
\hline SEM & 4.08 & 1.88 & 6.82 & 17.87 & 14.26 & 10.22 & 44.22 \\
\hline P-value & 0.0520 & 0.1015 & 0.0005 & 0.0117 & 0.0484 & 0.9276 & 0.0082 \\
\hline
\end{tabular}

${ }^{1} \mathrm{~T} 1$ : control diet; $\mathrm{T} 2$ : control diet $+0.25 \mathrm{~g} \mathrm{~kg}^{-1}$ of oxytetracycline (Bayer); and T3: control diet $+0.4 \mathrm{~g} \mathrm{~kg}^{-1} \mathrm{Mexican}_{\text {oregano oil }}(4.06 \%$ thymol and $60.62 \%$ carvacrol). Means $(\mathrm{n}=54)$ of body weight $(\mathrm{g})$ and feed intake in the same column with different letters are significantly different $(\mathrm{P}<0.05)$. SEM - standard error of the mean. 
concluded that the oil mix acted as a growth promoter, positively affecting production parameters. The current results with Mexican oregano oil were similar to those of Jamroz et al. (2005), Hong et al. (2012), and Silva Vázquez et al. (2015). Mountzouris et al. (2011) indicated that incorporating 125 and $250 \mathrm{mg} \mathrm{kg}^{-1}$ of a commercial phytogenic feed additive strengthened broiler production and improved efficiency and FI at the final stage. These results could be due to the properties of essential oils to enhance stimulation of digestive secretion, circulation, antioxidant and antimicrobial properties, and the immune status (Brenes and Roura, 2010; Sugiharto, 2014). Results of other studies demonstrated that phytobiotics improves the growth performance of broiler chickens (Windisch and Kroismayr, 2007; El-Ghany and Ismail, 2013). Thereby, the results obtained by Hong et al. (2012) and the current study with Mexican oregano oil suggest that Mexican oregano oil can be considered a natural growth promoter.

The effect of Mexican oregano essential oils on lipoproteins has not been widely reported. In the current study, at 42 days, significant statistical differences were found in CHOL, HDL, and LDL $(\mathrm{P}<0.05)$ but not in triglycerides and VLDL $(\mathrm{P}>0.05)$ (Table 4$)$. The oregano oil treatment group had the highest $\mathrm{CHOL}$ value, while

Table 3 - Effect of Mexican oregano oil on broiler feed efficiency and weekly body weight gain

\begin{tabular}{|c|c|c|c|c|c|c|c|}
\hline \multirow{2}{*}{ Treatment } & \multicolumn{7}{|c|}{ Day } \\
\hline & 7 & 14 & 21 & 28 & 35 & 42 & $1-42$ \\
\hline & \multicolumn{7}{|c|}{ Weekly body weight gain } \\
\hline $\mathrm{T} 1$ & 116.20 & 277.09 & 428.85 & 599.09 & 611.30 & $561.92 b$ & 437.03 \\
\hline $\mathrm{T} 2$ & 117.84 & 281.69 & 431.84 & 588.66 & 620.13 & $603.75 \mathrm{ab}$ & 441.95 \\
\hline $\mathrm{T} 3$ & 116.49 & 269.02 & 477.54 & 594.78 & 640.98 & $698.31 \mathrm{a}$ & 460.57 \\
\hline SEM & 3.97 & 9.39 & 15.08 & 14.76 & 19.93 & 17.09 & 9.25 \\
\hline \multirow[t]{2}{*}{ P-value } & 0.9496 & 0.4419 & 0.0638 & 0.8900 & 0.6112 & 0.0501 & 0.1661 \\
\hline & \multicolumn{7}{|c|}{ Feed efficiency } \\
\hline $\mathrm{T} 1$ & 1.75 & 0.94 & 1.32 & 1.67 & 2.08 & $2.13 \mathrm{a}$ & $2.10 \mathrm{a}$ \\
\hline $\mathrm{T} 2$ & 1.67 & 0.88 & 1.29 & 1.62 & 1.94 & $1.90 \mathrm{ab}$ & $1.85 \mathrm{ab}$ \\
\hline $\mathrm{T} 3$ & 1.60 & 0.90 & 1.20 & 1.59 & 1.88 & $1.60 \mathrm{~b}$ & $1.66 \mathrm{~b}$ \\
\hline SEM & 0.08 & 0.03 & 0.05 & 0.05 & 0.07 & 0.12 & 0.12 \\
\hline P-value & 0.3894 & 0.2371 & 0.2269 & 0.4984 & 0.1072 & 0.0184 & 0.03 \\
\hline
\end{tabular}

T1: control diet; T2: control diet $+0.25 \mathrm{~g} \mathrm{~kg}^{-1}$ of oxytetracycline (Bayer); and T3: control diet $+0.4 \mathrm{~g} \mathrm{~kg}^{-1} \mathrm{Mexican}$ oregano oil $(4.06 \%$ thymol and $60.62 \%$ carvacrol). Mean $(\mathrm{n}=54)$ of weekly body weight gain $\left[\mathrm{WBWG}=\left(\mathrm{BW}_{\text {current }}-\mathrm{BW}_{\text {previous }}\right) /\right.$ week] and feed efficiency $[\mathrm{FE}=\mathrm{FI} / \mathrm{WBWG}]$ in the same column with different letters are significantly different $(\mathrm{P}<0.05)$.

SEM - standard error of means.

Table 4 - Effect of Mexican oregano oil and oxytetracycline on broiler blood profiles at 42 days

\begin{tabular}{|c|c|c|c|c|c|}
\hline \multirow{2}{*}{ Blood parameter } & \multicolumn{3}{|c|}{ Treatment } & \multirow{2}{*}{ SEM } & \multirow{2}{*}{ P-value } \\
\hline & $\mathrm{T} 1$ & $\mathrm{~T} 2$ & $\mathrm{~T} 3$ & & \\
\hline \multicolumn{6}{|c|}{ Lipid and lipoprotein profile $\left(\mathrm{mg} \mathrm{dL}^{-1}\right)$} \\
\hline Cholesterol & $121.42 \mathrm{ab}$ & $104.16 b$ & $138.42 \mathrm{a}$ & 8.10 & 0.03 \\
\hline Triglycerides & 28.71 & 39.50 & 37.00 & 4.38 & 0.21 \\
\hline HDL & $69.00 \mathrm{ab}$ & $58.83 \mathrm{~b}$ & $72.14 \mathrm{a}$ & 4.06 & 0.05 \\
\hline LDL & $46.68 \mathrm{a}$ & $37.43 b$ & $45.51 \mathrm{ab}$ & 2.77 & 0.05 \\
\hline VLDL & 5.74 & 7.90 & 7.40 & 0.87 & 0.21 \\
\hline \multicolumn{6}{|l|}{ Blood biometrics } \\
\hline Leukocytes $\left(\mathrm{K} \mu \mathrm{L}^{-1}\right)$ & 17.96 & 18.24 & 18.59 & 0.49 & 0.65 \\
\hline Eosinophils $\left(\mathrm{K} \mu \mathrm{L}^{-1}\right)$ & 1.57 & 2.00 & 1.71 & 0.34 & 0.68 \\
\hline Heterophile $\left(\mathrm{K} \mu \mathrm{L}^{-1}\right)$ & 27.83 & 33.60 & 30.43 & 2.58 & 0.34 \\
\hline Lymphocytes $\left(\mathrm{K} \mu \mathrm{L}^{-1}\right)$ & $12,048.55$ & $10,745.00$ & $11,977.71$ & 611.96 & 0.29 \\
\hline Heterocytes $\left(\mathrm{K} \mu \mathrm{L}^{-1}\right)$ & $4,814.64$ & $5,887.00$ & $5,131.60$ & 359.12 & 0.13 \\
\hline Monocytes (\%vol) & 4.14 & 2.80 & 3.17 & 0.56 & 0.24 \\
\hline Eosinophils (\%vol) & 240.32 & 261.00 & 219.40 & 43.58 & 0.81 \\
\hline Erythrocytes $\left(10^{6} \mu \mathrm{L}^{-1}\right)$ & 2.73 & 2.50 & 3.01 & 0.28 & 0.49 \\
\hline Hematocrit (\%vol) & 37.50 & 36.33 & 38.29 & 1.10 & 0.46 \\
\hline Hemoglobin $\left(\mathrm{g} \mathrm{dL}^{-1}\right)$ & 12.51 & 12.11 & 12.76 & 0.37 & 0.46 \\
\hline MCV (fL) & 127.81 & 118.48 & 113.46 & 9.34 & 0.53 \\
\hline $\mathrm{MCH}(\mathrm{pg})$ & 47.28 & 47.01 & 44.96 & 5.90 & 0.95 \\
\hline
\end{tabular}

T1: control diet; T2: control diet $+0.25 \mathrm{~g} \mathrm{~kg}^{-1}$ oxytetracycline (Bayer); T3: control diet $+0.4 \mathrm{~g} \mathrm{~kg}^{-1} \mathrm{Mexican}$ oregano oil (4.06\% thymol and $60.62 \%$ carvacrol).

HDL - high-density lipoprotein; LDL - low-density lipoprotein; VLDL - very low-density lipoprotein; K $\mu \mathrm{L}^{-1}$ - thousands per microliter; MCV - corpuscular volume; fL femtoliters; MCH - mean corpuscular hemoglobin (pg - picogram); SEM - standard error of means.

Means in the same row with different letters are significantly different $(\mathrm{P}<0.05)$. 
Table 5 - Effect of Mexican oregano oil on broiler slaughter variables at 42 days

\begin{tabular}{lccccc}
\hline \multirow{2}{*}{ Slaughter variable } & \multicolumn{3}{c}{ Treatment } & & \\
\cline { 2 - 4 } & T1 & T2 & T3 & & P-value \\
\hline Slaughter weight & $2,552.22$ & $2,718.64$ & $2,771.78$ & 0.08 & 0.18 \\
Hot carcass weight & $2,080.36$ & $2,112.52$ & $2,252.21$ & 0.08 & 0.33 \\
Cold carcass weight & $2,109.48$ & $2,136.48$ & $2,274.62$ & 0.08 & 0.36 \\
Hot carcass yield & $2,163.27$ & $2,188.76$ & $2,332.52$ & 0.09 & 0.34 \\
Cold carcass yield & $2,189.67$ & $2,214.35$ & $2,357.27$ & 0.08 & 0.35 \\
\hline
\end{tabular}

T1: control diet; $\mathrm{T} 2$ : control diet $+0.25 \mathrm{~g} \mathrm{~kg}^{-1}$ oxytetracycline (Bayer); $\mathrm{T} 3$ : control diet $+0.4 \mathrm{~g} \mathrm{~kg}^{-1}$ Mexican oregano oil (4.06\% thymol and $60.62 \%$ carvacrol).

SEM - standard error of means.

the antibiotic treatment had the lowest CHOL, HDL, and LDL values. These results were similar to those of Cho et al. (2014), although their results on CHOL were lower compared with the results obtained in this study with Mexican oregano oil, in which oregano oil treatment increased the total CHOL $(\mathrm{P}<0.05)$ as well as $\mathrm{HDL}$ $(\mathrm{P}<0.05)$. These results partially agree with Hong et al. (2012), who found that essential oils reduced total CHOL, decreased VLDL, and increased HDL. Contrasting results were presented by Najafi and Torki (2010), who found no effect on cholesterol and HDL when studying essential oils in the diet. Results in blood biometrics were not different among treatments at 42 days ( $\mathrm{P}>0.05$ ) (Table 4$)$. In general, the blood biometrics of the three treatment groups were within normal ranges. Broilers given Mexican oregano oil had slightly increased white blood cells, erythrocytes, and hemoglobin. The control group had high values of mean corpuscular volume, lymphocytes, monocytes, and mean corpuscular hemoglobin, followed by antibiotic and MOO treatment groups. Treatment with oxytetracycline increased, but not significantly, the levels of heterophiles and eosinophils.

No significant statistical differences $(\mathrm{P}>0.05)$ were found among treatments regarding meat production variables. In the current study, the group treated with $\mathrm{MOO}$ had high values among slaughter variables, followed by control and oxytetracycline treatment groups (Table 5). Similar results were observed in hot carcass weight, cold carcass weight, hot carcass yield, and cold carcass yield by Mendez-Zamora et al. (2015) and by Kırkpınar et al. (2014) only on carcass yields.

\section{Conclusions}

Supplementation of $0.4 \mathrm{~g} \mathrm{~kg}^{-1}$ of Mexican oregano oil has positive effect on body weight, feed intake, and feed efficiency. Mexican oregano oil can be used as a supplement in the diet of broilers to improve health and slaughter parameters.

\section{Acknowledgments}

This study was supported by Facultad de Zootecnia y Ecologia, Universidad Autónoma de Chihuahua, which provided the installations and some ingredients of diets.

\section{References}

Adil, S.; Banday, T.; Ahmad Bhat, G.; Salahuddin, M.; Raquib, M. and Shanaz, S. 2011. Response of broiler chicken to dietary supplementation of organic acids. Journal of Central European Agriculture 12:498-508.

Basmacıoğlu, H.; Tokuşoğlu, Ö. and Ergül, M. 2004. The effect of oregano and rosemary essential oils or alpha-tocopheryl acetate on performance and lipid oxidation of meat enriched with n-3 PUFA's in broilers. South African Society for Animal Science 34:197-210.

Benjamin M. N. 1984. Manual de patología clínica veterinaria. 3. ed. Limusa, Mexico. 421p.

Bozkurt, M.; Küçükyılmaz, K.; Çatlı, A. U. and Çınar, M. 2009. Effect of dietary mannan oligosaccharide with or without oregano essential oil and hop extract supplementation on the performance and slaughter characteristics of male broilers. South African Society for Animal Science 39:223-232.

Brenes, A. and Roura, E. 2010. Essential oils in poultry nutrition: mail effects and modes of action. Animal Feed Science and Technology $158: 1-14$.

Cabuk, M.; Bozkurt, M.; Alcicek, A.; Akbas, Y. and Kücüyilmaz, K. 2006. Effect of an herbal essential oil mixture on growth and internal organ weight of broilers from young and old breeder flocks. South African Society for Animal Science 36:135-141.

Cho, J. H.; Kim, I. H. and Kim, I. J. 2014. Effects of phytogenic feed additive on growth performance, digestibility, blood metabolites, intestinal microbiota, meat color and relative organ weight after oral challenge with clostridium perfringens in broilers. Livestock Science 160:82-88.

Cohn, J. S.; McNamara, J. R. and Schaefer, E. J. 1988. Lipoprotein cholesterol concentrations in the plasma of human subjects as measured in the fed and fasted states. Clinical Chemistry $34: 2456-2459$.

Dunford, N. T. and Silva, V. R. 2005. Effect of water stress on plant growth and thymol and carvacrol concentrations in Mexican oregano grown under controlled conditions. Journal of Applied Horticulture 7:20-22.

El-Ghany, W. A. A. and Ismail, M. 2013. Tackling of experimental colisepticaemia in broiler chickens using phytobiotic essential oils and antibiotic alone or in combination. Iranian Journal of Veterinary Research 15:110-115.

Gopi, M.; Karthik, K.; Manjunathachar, H. V.; Tamilmahan, P.; Kesavan, M.; Dashprakash, M.; Balaraju, B. L. and Purushothaman, M. R. 2014. Essential oils as a feed additive in poultry nutrition. Advances in Animal and Veterinary Sciences 2:1-7.

Hashemipour, H.; Khaksar, V.; Rubio, L.A.; Veldkamp, T. and van Krimpen, M. M. 2016. Effect of feed supplementation with a thymol plus carvacrol mixture, in combination or not with an NSPdegrading enzyme, on productive and physiological parameters of broilers fed on wheat-based diets. Animal Feed Science and Technology 211:117-131.

Hassanpour, H.; Moghaddam, A. K. Z.; Khosravi, M. and Mayahi, M. 2013. Effects of synbiotic on the intestinal morphology and humoral immune response in broiler chickens. Livestock Science 153:116-122. 
Hippenstiel, F.; Abdel-Wareth, A.A.A.; Kehraus, S. and Südekum, K.-H. 2011. Effects of selected herbs and essential oils, and their active components on feed intake and performance of broilers - a review. Archiv fur Geflügelkunde 75:226-234.

Hong, J. C.; Steiner, T.; Aufy, A. and Lien, T. F. 2012. Effects of supplemental essential oil on growth performance, lipid metabolites and immunity, intestinal characteristics, microbiota and carcass traits in broilers. Livestock Science 137:219-225.

INEGI - Instituto Nacional de Estadística y Geografía e Informatica. 2013. Mexico en cifras: Información Nacional por Entidad Federativa y Municipios. Available at: <www3.inegi.org.mx/ sistemas/mexicocifras/default.aspx.>. Accessed on: Dec. 14, 2013.

Jamroz, D.; Orda, J.; Kamel, C.; Wiliczkiewicz, A.; Wertelecki, T. and Skorupinska, J. 2005. The influence of phytogenic extracts on performance, nutrient digestibility, carcass characteristics and gut microbial status in broiler chickens. Journal of Animal and Feed Sciences 12:583-596.

Karimi, A.; Yan, F.; Coto, C.; Park, J. H.; Min, Y.; Lu, C.; Gidden, J. A.; Lay Jr., J. O. and Waldroup, P. W. 2010. Effect of level and source of oregano leaf in starter diets for broiler chicks. Journal of Applied Poultry Research 19:137-145.

Kırkpınar, F.; Ünlü, H. B. and Özdemir, G. 2011. Effects of oregano and garlic essential oils on performance, carcase, organ and blood characteristics and intestinal microflora of broilers. Livestock Science 137:219-225.

Kırkpınar, F.; Ünlü, H. B., Serdaroğlu, M. and Turp, G. Y. 2014. Effects of dietary oregano and garlic essential oils on carcass characteristics, meat composition, colour, $\mathrm{pH}$ and sensory quality of broiler meat. British Poultry Science 55:157-166.

Küçükyılmaz, K.; Bozkurt, M.; Çınar, M.; Çatlı, A. U.; Bintaş, E. and Erkek, R. 2014. The effects of an organic rearing system and dietary supplementation of an essential oil mixture on performance and meat yield of slow-growing broilers in two seasons. South African Journal of Animal Science 44:360-370.

Lee, K.; Everts, H.; Kappert, H. J.; Frehner, M.; Losa, R. and Beynen, A. C. 2003. Dietary carvacrol lowers body weight but improves feed conversion in female broiler chickens. Journal of Applied Poultry Research 12:394-399.

Medway, W.; Prier, J. E. and Wilkinson, J. S. 1969. A textbook of veterinary clinical pathology. Williams \& Wilkins Co, Baltimore, Inglaterra. 522p.

Mendez-Zamora, G.; García-Macías, J. A.; Durán-Meléndez, L. A.; Herman-Lara, E.; Santellano-Estrada, E. and Silva-Vazquez, R. 2015. Aceite esencial de orégano (Lippia berlandieri Schauer) en variables de calidad de la canal de pollo. Ecosistemas y Recursos Agropecuarios 2:41-51

Mohiti-Asli, M. and Ghanaatparast-Rashti, M. 2015. Dietary oregano essential oil alleviates experimentally induced coccidiosis in broilers. Preventive Veterinary Medicine 120:195-202.

Mountzouris, K. C.; Paraskevas, V.; Tsirtsikos, P.; Palamidi, I.; Steiner, T.; Schatzmayr, G. and Fegeros, K. 2011. Assessment of a phytogenic feed additive effect on broiler growth performance, nutrient digestibility and caecal microflora composition. Animal Feed Science and Technology 168:223-231.

Najafi, P. and Torki, M. 2010. Performance, blood metabolites and immunocompetence of broiler chicks fed diets included essential oils of medicinal herbs. Journal of Animal and Veterinary Advances 9:1164-1168.

NOM-062-ZOO-1999. 1999. Norma Oficial Mexicana, especificaciones técnicas para la producción, cuidado y uso de animales de laboratorio. Available at: $<\mathrm{http} / / \mathrm{www}$.economia-noms. gob.mx/noms/consultasAction.do>. Accessed on: Nov. 20, 2015.

NRC - National Research Council. 1994. Nutritional requirements of poultry. 9th ed. National Academy Press, Washington, DC.

Ocak, N.; Erener, G.; Burak, A. K.; Sungu, F.; Altop, M. and Ozmen, A. 2008. Performance of broilers fed diets supplemented with dry peppermint (Mentha piperita L.) or thyme (Thymus vulgaris L.) leaves as growth promoter source. Czech Journal of Animal Science 53:169-175.

Park, J. H.; Kang, S. N.; Chu, G. M. and Jin, S. K. 2014. Growth performance, blood cell profiles, and meat quality properties of broilers fed with Saposhnikovia divaricata, Lonicera japonica, and Chelidonium majus extracts. Livestock Science 165:87-94.

Silva Vázquez, R; Durán Meléndez, L. A.; Santellano Estrada, E.; Rodríguez Muela, C.; Villalobos Villalobos, G.; Méndez Zamora, G. and Hume, E. M. 2015. Performance of broiler chickens supplemented with Mexican oregano oil (Lippia berlandieri Schauer). Revista Brasileira de Zootecnia 44:283-289.

Silva, V. R. and Dunford, T. N. 2005. Bioactive components of mexican oregano oil as affected by moisture and plant maturity. Journal of Essential Oil Research 17:668-671.

Sugiharto, S. 2014. Role of nutraceuticals in gut health and growth performance of poultry. Journal of the Saudi Society of Agricultural Sciences, <http://dx.doi.org/10.1016/j.jssas.2014.06.001>. Accessed on: Nov. 25, 2015.

Symeon, G. K.; Zintilas, C.; Ayoutanti, A.; Bizelis, J. A. and Deligeorgis, S. G. 2009. Effect of dietary oregano essential oil supplementation for an extensive fattening period on growth performance and breast meat quality of female medium-growing broilers. Canadian Journal of Animal Science 89:331-334.

Tiihonen, K.; Kettunen, H.; Bento, M. H.; Saarinen, M.; Lathinen, S.; Ouwe-hand, A. C.; Sculze, H. and Rautonen, N. 2010. The effect of feeding essential oils on broiler performance and gut microbiota. British Poultry Science 51:381-392.

Wang, Z. and Goonewardene, L. A. 2004. The use of MIXED models in the analysis of animal experiments with repeated measures data. Canadian Journal of Animal Science 84:1-11.

Windisch, W. and Kroismayr, A. 2007. Natural phytobiotics for health of young piglets and poultry: mechanisms and application. Poultry Science 86(Suppl. 1):643.

Zhang, K. Y.; Yan, F.; Keen, C. A. and Waldroup, P. W. 2005. Evaluation of microencapsulated essential oils and organic acids in diets for broiler chickens. International Journal of Poultry Science 4:612-619. 